\title{
Sarcina infection
}

\author{
G Balan Louis, Priya Singh, Kim Vaiphei
}

Department of Histopathology, PGIMER, Chandigarh, India

\section{Correspondence to}

Professor Kim Vaiphei, kvaiphei2009@gmail.com

\section{DESCRIPTION}

A 50-year-old man, a chronic alcoholic with hepatitis $\mathrm{C}$ virus positive status, presented with jaundice and right upper quadrant pain for 2 months. He had a history of taking antitubercular drugs for 2 years. General physical examination revealed icterus; systemic examinations were within the normal limits. His bilirubin level was $6.95 \mathrm{mg} / \mathrm{dL}$, alkaline phosphatase $1720 \mathrm{U} / \mathrm{L}$ and rest of liver function test parameters were within the normal limits. Ultrasonography examination of the abdomen showed mild splenomegaly and haepatomegaly, gallbladder with biliary sludge, dilated intrahepatic biliary radical (IHBRD) and mural thickening in the pyloric region. Magnetic resonance computerised topography showed dilated IHBRDs, choledocolithiasis, cholelithiasis, mild haepatomegaly and minimal ascites. $\mathrm{He}$ was diagnosed with extrahepatic biliary obstruction by multiple stones in the gallbladder and common bile duct, and gastric outlet obstruction. Upper gastrointestinal endoscopy showed normal oesophagus, stomach showed hyperaemia and mucosal oedema at pylorus with food residue. Scope was negotiable to the first

(a)

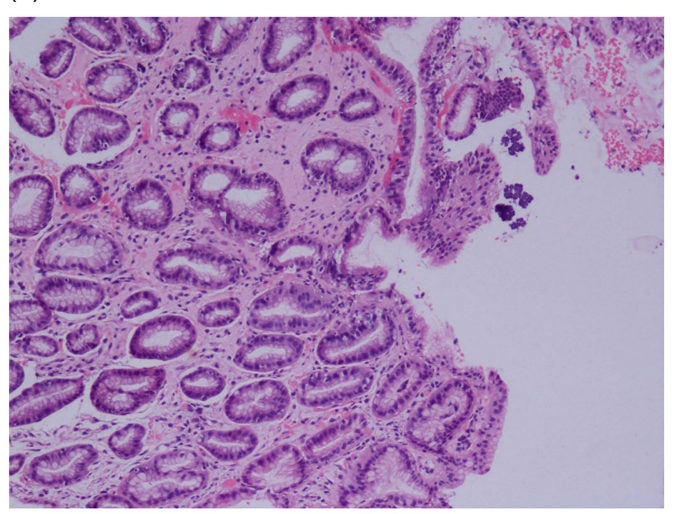

part of the duodenum, which also showed food residues, and normal second part of the duodenum. Antral biopsy was taken. On histopathology, biopsy showed intact epithelial lining with focal intestinal metaplasia. The lamina propria showed mild to moderately heavy lymphoplasmacytic cell infiltration with lamina propria fibrosis. No active inflammation or Helicobacter pylori or dysplasia was observed. In addition, there were many intensely haematoxylinophilic spherical organisms in tetrads and octets on gastric mucosa which were positive on Gram staining. These organisms had the morphology of Sarcina ${ }^{1-3}$ (figure 1A-C). No invasion of gastric mucosa was seen. A diagnosis of chronic gastritis with intestinal metaplasia with the presence of Sarcina was made.

Following the endoscopic report, he was given metronidazole $(250 \mathrm{mg})$ three times daily and ciprofloxacin $(250 \mathrm{mg})$ twice daily for 1 week along with sucralfate. Repeat endoscopy and gastric biopsy after the treatment showed an improvement in the gastritis status and no similar organism could be identified in the biopsy.

(c)

(b)

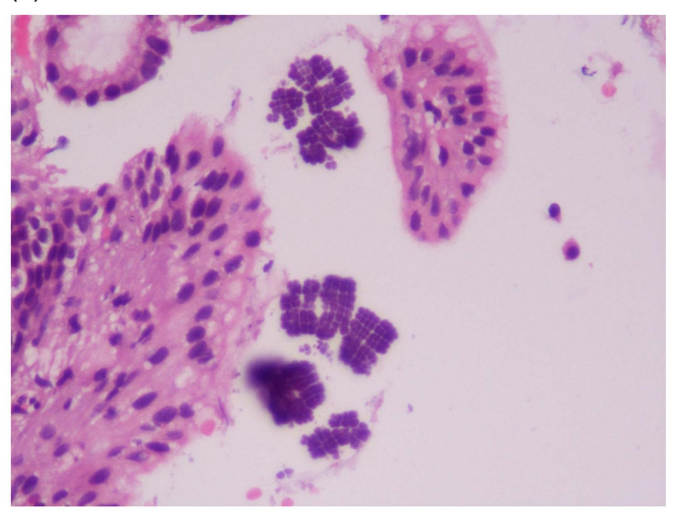

To cite: Louis GB, Singh $P$, Vaiphei K. BMJ Case Rep Published online: [please include Day Month Year] doi:10.1136/bcr-2013201185

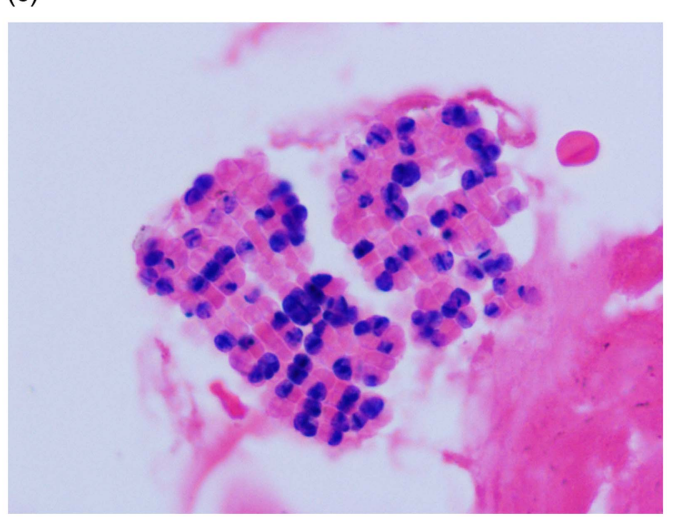

Figure 1 (A) Low-power photomicrograph of the antral biopsy showing lamina propria inflammation with fibrosis and intact mucosal lining epithelium. There are many intensely haematoxylinophilic spherical organisms overlying the mucosa $(H \& E, \times 250)$. (B) High microphotograph showing the character of those haematoxylinophilic spherical organisms having characteristic and regular tetrads and octets shapes $(H \& E, \times 500)$. (C) High microphotograph showing Gram positivity of the organisms (Gram stain, $\times 1000)$. 


\section{Learning points}

- The histological features of Sarcina are singular enough that a diagnosis can be made on routine H\&E staining.

- Infection and colonisation of Sarcina is usually associated with functional gastric outlet obstruction and delayed gastric emptying such as occult malignancy.

- The need for antibiotic treatment for Sarcina in a clinically stable patient is unclear. However, a definite endoscopic and histological improvement has been observed by treating the patient.
Contributors GBL, PS and KV contributed equally in reporting and writing the paper.

Competing interests None.

Patient consent Obtained.

Provenance and peer review Not commissioned; externally peer reviewed.

\section{REFERENCES}

1 Lam-Himlin D, Tsiatis AC, Montgomery E, et al. Sarcina organisms in the gastrointestinal tract: a clinicopathologic and molecular study. Am J Surg Pathol 2011;35:1700-5.

2 Canale-Parola E. Biology of the sugar fermenting sarcinae. Bacteriol Rev 1970;34:82-97.

3 Canale-Parola E, Sneath NS, Mair ME, et al. Genus Sarcina. In: Bergey's manual of systematic bacteriology. Philadelphia: Williams \& Wilkins, 1986;2:1100-3.

Copyright 2014 BMJ Publishing Group. All rights reserved. For permission to reuse any of this content visit http://group.bmj.com/group/rights-licensing/permissions.

BMJ Case Report Fellows may re-use this article for personal use and teaching without any further permission.

Become a Fellow of BMJ Case Reports today and you can:

- Submit as many cases as you like

- Enjoy fast sympathetic peer review and rapid publication of accepted articles

- Access all the published articles

- Re-use any of the published material for personal use and teaching without further permission

For information on Institutional Fellowships contact consortiasales@bmjgroup.com

Visit casereports.bmj.com for more articles like this and to become a Fellow 